\title{
Litter size, lamb survival, birth and twelve week weight in lambs born to cross-bred ewes
}

\author{
B.C. THOMSON, P. D. MUIR and N.B. SMITH \\ On-Farm Research Ltd, P.O. Box 1142, Hastings \\ bev@on-farm.co.nz
}

\begin{abstract}
This study looked at ewe effects on the number of lambs reared (litter size and mortality) and lamb 12 week weight (birth weight and growth rate). Over six years, data was collected on 5571 lambs born to around 3390 Romney (R), Finn cross Romney (F x R), East Friesian cross Romney (EF x R) and Poll Dorset cross Romney (PD x $\mathrm{R})$ ewes. Ewe live weights were recorded pre-lambing and 12 weeks post-lambing. Lambs were weighed at birth and 12 weeks post-lambing. Ewe effects played a significant role in affecting the productivity of the system and many effects were cumulative. Over six years, the lambing percentage (lambs born/ewes lambing) was 165 $\%$. Two tooth ewes had lower lambing percentages than the mixed age ewes (155 vs $170 \%$ ). Lambing percentages were $186 \%$ for F x R, $171 \%$ for the EF x R, $155 \%$ for the PD x R and $153 \%$ for the R ewes.

Birth weights ranged from $1 \mathrm{~kg}$ to $9.8 \mathrm{~kg}$, with a mean of $4.8 \mathrm{~kg}$. Lambs born to F x R ewes $(4.28 \mathrm{~kg})$ were significantly lighter at birth than those born to PD $\mathrm{x} R$ ewes $(5.34 \mathrm{~kg})$. On average, $5 \%$ of lambs were dead at tagging and $11 \%$ of all lambs born were not present at $12 \mathrm{wks}$ of age. The relationship between birth weight and mortality differed to previously published New Zealand reports with high survival rates in the present study over a wide range of birth weights from 3 to $9 \mathrm{~kg}$. It is likely that changes in management practices (improved nutrition, heavier ewes, and selection for easy care lambing) may have contributed to the reduced mortality rates in the heavier lambs in the present study. Ewe genotype modified the effect of birth rank on birth weight and mortality. The average penalty for each additional lamb was smaller for the progeny of the EF $x$ $\mathrm{R}$ and $\mathrm{F} x \mathrm{R}$ ewes ( 0.85 and $0.88 \mathrm{~kg}$, respectively) than for the progeny of the R and PD $x$ R ewes (1.09 and 1.17 $\mathrm{kg}$, respectively). Triplets born to $\mathrm{R}$ ewes had significantly lower survival rates than the other lambs. Heavier birth weights are likely to result in heavier lambs at 12 weeks of age that can be sold earlier.
\end{abstract}

Keywords: birth rank, birth weight, ewe breed, lamb growth, lamb survival

\section{Introduction}

There is an increasing interest in improving productivity through increasing the number of lambs weaned per ewe and increasing lamb growth rates. In 1998, the Poukawa Elite Lamb flock was established to demonstrate a high performance system on a 88 ha block that was part of the Poukawa farm in the Central Hawkes Bay. The flock comprised approximately 900 Romney (R), Finn cross Romney (F x R), East Friesian cross Romney (EF x R) and Poll Dorset cross Romney (PD x R) recorded ewes which were mated to terminal and dual purpose sires in a Central Progeny Test. This demonstration is on-going. The data collected so far was used to examine the dam effects on two factors affecting productivity; number of lambs reared and lamb 12 week weight.

\section{Materials and methods}

Over six years (1998 - 2003), data was collected on 5571 lambs born to Romney (R) ewes, Finn cross Romney (F x R) ewes, East Friesian cross Romney (EF $x$ R) ewes and Poll Dorset cross Romney (PD x R) ewes. Ewes were farmed as one mob on an area of generally old pasture (comprising ryegrass, annual grasses, and sub clover) and flat to rolling terrain. The block was managed under as close to commercial conditions as possible while still maximizing ewe productivity. Pasture cages and rising plate meter measurements are recorded in every paddock monthly. Soil tests are carried out annually and fertiliser applied as required. Supplements (silage and barley) were fed as required. Ewes were drafted into single-, twin- and tripletlambing mobs, based on pregnancy scanning data, and were set stocked within 1 week of lambing. Ewes are lambed onto as good as covers as possible, usually around $1600 \mathrm{~kg}$ dry matter (DM)/ha. The majority of ewes lambed in the last week of July. Ewes were vaccinated against clostridial diseases and preventative treatments for internal and external parasites were administered. Ewes were weighed pre-mating, scanning, pre-lambing and 12 weeks post-lambing. Lambs were weighed at birth and tagged usually within 18 hours of birth and 12 weeks post-lambing.

Data was analysed using the GLM, Chi and REG procedures in Minitab (Version 3.13, Minitab Inc.). Year, ewe breed, ewe age, ewe liveweight, birth rank, sire breed and sex of the lamb were adjusted for in the model where appropriate. Tukeys tests were used to compare the LSD means.

\section{Results and discussion}

Over six years, the mean lambing percentage (lambs born/ewes lambing) was $165 \%$. Two tooth ewes had a 
Table 1 Effect of ewe age (year) on the lambing percentage (lambs born/ewe lambing), lamb mortality up to 12 weeks of age and birth weight $(\mathrm{kg})$, (raw means, for age comparisons numbers with different superscripts are significantly different after correction for birth rank and breed $(P<0.05))$.

\begin{tabular}{ccccc}
\hline Ewe age & Number of lambs & Lambing \% & \% lambs died & Birth weight \\
\hline 2 & 1208 & $155^{\mathrm{a}}$ & $14.7^{\mathrm{a}}$ & $4.76^{\mathrm{a}}$ \\
3 & 1279 & $168^{\mathrm{b}}$ & $11.6^{\mathrm{b}}$ & $4.66^{\mathrm{ab}}$ \\
4 & 1057 & $165^{\mathrm{b}}$ & $9.7^{\mathrm{b}}$ & $5.16^{\mathrm{b}}$ \\
5 & 1140 & $173^{\mathrm{bc}}$ & $10.1^{\mathrm{b}}$ & $4.91^{\mathrm{b}}$ \\
6 & 684 & $180^{\mathrm{c}}$ & $8.9^{\mathrm{b}}$ & $4.84^{\mathrm{b}}$ \\
7 & 197 & $163^{\mathrm{abc}}$ & $7.6^{\mathrm{b}}$ & $5.31^{\mathrm{b}}$ \\
\hline
\end{tabular}

Figure 1 Number of lambs born within each birth weight category and the percentage of mortality prior to 12 weeks of age.

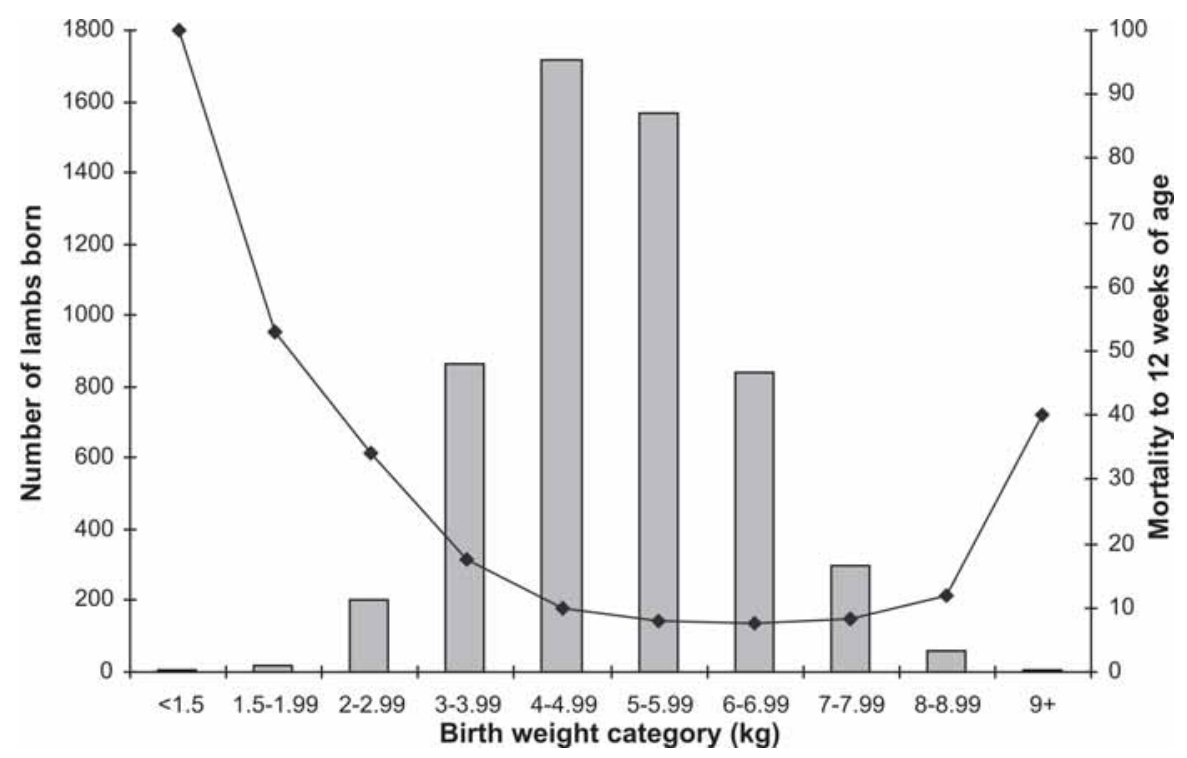

Table 2 Effect of ewe genotype and litter size on lamb birth weights $(\mathrm{kg})$, (raw means presented, means with different superscripts are significantly different $(P<0.05))$.

\begin{tabular}{|c|c|c|c|c|}
\hline Ewe genotype & 1 & $\begin{array}{c}\text { Litter size } \\
2\end{array}$ & 3 & Mean \\
\hline$E F \times R$ & 5.94 & 4.88 & 4.26 & $5.05^{\mathrm{b}}$ \\
\hline $\mathrm{F} \times \mathrm{R}$ & 5.28 & 4.28 & 3.70 & $4.28^{a}$ \\
\hline$P D \times R$ & 6.19 & 5.04 & 4.10 & $5.34^{\circ}$ \\
\hline $\mathrm{R}$ & 5.87 & 4.81 & 3.58 & $5.08^{\mathrm{ab}}$ \\
\hline Mean & $5.83^{c}$ & $4.71^{\mathrm{b}}$ & $3.91^{\mathrm{a}}$ & \\
\hline
\end{tabular}

Table 3 Relative influence of birth rank (BR), sex of the lamb, ewe pre-mating weight $(\mathrm{kg})$ and ewe pre-lamb weight $(\mathrm{kg})$ on lamb birth weight $(\mathrm{kg})$ within ewe genotype.

\begin{tabular}{lccccc}
\hline & Direction & EF $\times \mathrm{R}$ & $\mathrm{F} \times \mathrm{R}$ & $\mathrm{PD} \times \mathrm{R}$ & $\mathrm{R}$ \\
\hline Birth rank & - & 0.85 & 0.88 & 1.09 & 1.17 \\
Ram vs ewe & + & 0.30 & 0.32 & 0.48 & 0.36 \\
Pre-mate wt & + & 0.014 & 0.014 & 0.02 & 0.015 \\
Pre-lamb wt & + & 0.009 & 0.00 & 0.015 & 0.020 \\
$\mathrm{R}^{2}$ & & 29.9 & 32.3 & 34.1 & 35.4 \\
$\mathrm{P}$ & & 0.001 & 0.001 & 0.001 & 0.001 \\
\hline
\end{tabular}


Table 4 Effect of litter size and ewe genotype on lamb mortality (\%) to 12 weeks of age (raw means presented, means with different superscripts are significantly different $(P<0.05))$.

\begin{tabular}{|c|c|c|c|c|}
\hline \multirow[b]{2}{*}{ Ewe genotype } & \multicolumn{3}{|c|}{ Litter size } & \multirow[b]{2}{*}{ Mean } \\
\hline & 1 & 2 & 3 & \\
\hline$E F \times R$ & 7.5 & 9.3 & 18.7 & $13.0^{\mathrm{ab}}$ \\
\hline$F \times R$ & 9.9 & 6.7 & 21.6 & $12.6^{\mathrm{a}}$ \\
\hline$P D \times R$ & 9.0 & 7.5 & 11.1 & $9.7^{\mathrm{a}}$ \\
\hline $\mathrm{R}$ & 7.3 & 13.4 & 39.3 & $18.8^{\mathrm{b}}$ \\
\hline Mean & $8.9^{\mathrm{a}}$ & $10.3^{a}$ & 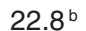 & \\
\hline
\end{tabular}

Table 5 Effect of dam genotype and birth rank on lamb weight $(\mathrm{kg})$ at 12 weeks of age, (raw means presented, for breed comparisons numbers with different superscripts are significantly different; $\mathrm{P}<0.05$ ).

\begin{tabular}{lrrrr}
\hline & & Birth rank & 3 & Mean \\
\cline { 2 - 4 } Ewe genotype & 1 & 2 & 28.0 & $32.5^{\mathrm{c}}$ \\
EF x R & 36.3 & 32.0 & 25.9 & $28.1^{\mathrm{a}}$ \\
F x R & 32.0 & 27.8 & 29.2 & $32.1^{\mathrm{c}}$ \\
PD x R & 36.2 & 30.3 & 26.6 & $29.8^{\mathrm{b}}$ \\
R & 32.7 & 28.4 & $26.8^{\mathrm{c}}$ & \\
Mean & $33.9^{\mathrm{a}}$ & $29.5^{\mathrm{b}}$ & & \\
\hline
\end{tabular}

Table 6 Relative effects of birth rank, sex, birth weight and ewe live weight at mating on lamb live weight (kg) at 12 weeks of age.

\begin{tabular}{lccccc}
\hline & & \multicolumn{3}{c}{ Dam breed } & \\
\cline { 3 - 5 } & & EF x R & F x R & R & PD $\times$ R \\
\hline Birth rank & - & 2.78 & 2.45 & 1.96 & 3.07 \\
Ram vs ewe & + & 2.49 & 2.24 & 2.16 & 1.94 \\
Birth wt & + & 1.61 & 1.24 & 1.67 & 1.19 \\
Pre-mating ewe wt & + & 0.09 & 0.13 & 0.08 & 0.18 \\
$\mathrm{R}^{2}$ & & 29.0 & 35.7 & 28.5 & 29.9 \\
$\mathrm{P}$ & & 0.001 & 0.001 & 0.001 & 0.001 \\
\hline
\end{tabular}

lower lambing percentage than the mixed age ewes (Table 1). Lambing percentages were $186 \%$ for $\mathrm{F} x \mathrm{R}, 171 \%$ for the EF x R, $155 \%$ for the PD x R and $153 \%$ for the $\mathrm{R}$ ewes.

Ewe liveweight pre-mating had a small, but significant $(\mathrm{P}<0.05)$, effect on lambing percentage, with an average increase of $1 \%$ per $\mathrm{kg}$ of ewe liveweight $(1.3,1.3,1.1$ and $0.7 \%$ for $\mathrm{F} \times \mathrm{R}, \mathrm{R}, \mathrm{EF} \times \mathrm{R}$ and PD $\mathrm{x}$ R ewes, respectively). This is similar to the $1.3 \%$ increase reported by Coop $(1962,1966)$.

Birth weights ranged from 1 to $9.8 \mathrm{~kg}$ (Figure 1), although lambs weighing less than $1.5 \mathrm{~kg}$ did not survive. This range is wider (Figure 1) and the birth weights of singles and twins (Table 2) higher than many previous reports. For example Hinch et al. (1985) reported mean weights of $4.1-4.9 \mathrm{~kg}$ for single lambs and $3.4-3.6 \mathrm{~kg}$ for twin lambs born to Booroola Merinos and Hight \& Jury (1970) reported mean birth weights of 3.8 - $4.4 \mathrm{~kg}$ for single lambs born to Romney and Border Leicester $\mathrm{x}$ Romney ewes. As found by Hight \& Jury (1969), lambs born to two-tooth ewes were significantly lighter than those born to older ewes (4.76 vs $4.90 \mathrm{~kg}$ ). Ram lambs were $0.32 \mathrm{~kg}$ heavier than ewe lambs - this was comparable to the differences reported by Dalton et al. (1980) and Hight \& Jury (1970). The progeny of the F x R ewes were lighter at birth and the progeny of the PD $x$ $\mathrm{R}$ ewes heavier than the progeny of the other two ewe genotypes (Table 2). Lambs from larger litters were smaller, with on average a $1 \mathrm{~kg}$ disadvantage for every additional lamb. This was similar to that found by Morris et al. (2003). However, in the present study, the birth weight disadvantage for multiple births was smaller in ewes with higher lambing percentages ( $\mathrm{F} \times \mathrm{R}$ and $\mathrm{EF} \mathrm{x}$ $\mathrm{R}$ ewes) than in the genotypes with lower lambing percentages (PD x R and R ewes, Table 3). Overall, within a genotype, ewe mating weight had a small but significant effect $(\mathrm{P}<0.05)$ on birth weight with an increase of 14 to $20 \mathrm{~g}$ in birth weight for each extra $1 \mathrm{~kg}$ of ewe mating weight (Table 3 ).

On average, $5 \%$ of all lambs born were dead at tagging and $11 \%$ of all lambs born were dead or missing 12 weeks post-lambing. More of the lambs born to two- 
tooth ewes were dead at tagging than the lambs born to mixed aged ewes ( $7.8 \%$ vs $4.0 \%$ respectively) and similarly at 12 weeks of age (Table 1 ). This was probably due to the size of the lambs and the size and experience of the ewes. Previous New Zealand work observed similar age effects on lamb birth weight (Hight \& Jury 1969, 1970; Dalton et al. 1980).

Lamb survival was consistent over the range of birth weight from 3 to $9 \mathrm{~kg}$. The lambs outside this weight range accounted for $23 \%$ of the deaths, but were only 4 $\%$ of the lambs born (Figure 1). Deaths of lambs over 9 $\mathrm{kg}$ were probably due to dystocia as they occurred pretagging. In lambs lighter than $3 \mathrm{~kg}, 17 \%$ were dead at tagging and $20 \%$ died later, suggesting that some deaths were due to starvation/exposure. In contrast to previous reports suggesting $50 \%$ mortality above $6.5 \mathrm{~kg}$ (Hight \& Jury 1970; Dalton et al. 1980; Hinch et al. 1985), in this study there was no effect of birth weight on mortality from 3 to $9 \mathrm{~kg}$. This is probably due to changes in genotype (e.g. selection for easy care lambing and new breeds) and improved nutrition. The increase in ewe weight means that the single lamb birth weight (mean birth weight $5.9 \mathrm{~kg}$ ) represents $8.9 \%$ of the EF x ewe live weight (mean weight $70 \mathrm{~kg}$ ) - this is comparable to the $8.9-10.6 \%$ calculated for joining weights of 44 - 48 $\mathrm{kg}$ (Hinch et al. 1985). A $9 \mathrm{~kg}$ lamb birth weight is the equivalent to $13.8-12.9 \%$ of the liveweight of a $65-70$ $\mathrm{kg}$ ewe and is similar to the $14.4-13.0 \%$ for the $6.5 \mathrm{~kg}$ lamb (Hight \& Jury 1970) assuming its dam weighed 45 - $50 \mathrm{kgs}$. In light of these results, it may be time to reexamine the recommendation to optimize birth weights between 3.2 and $5.5 \mathrm{~kg}$ (Geenty 1997) for well fed large, high performing ewes. Increasing the range of birth weights within a triplet set did not decrease survivability, with mortalities of 24,18 and $13 \%$ for birth weight spreads of 1, 2 and $3 \mathrm{~kg}$ respectively. More triplet lambs born to Romney ewes (39\%) died than for the other genotypes (Table 4). Morris et al. (2003) also reported losses of $32 \%$ in Romney triplet lambs. The milk production of Romney ewes varies widely (Muir unpublished data) and so it is possible that a smaller number of Romney ewes are capable of successfully rearing triplets.

In general as expected, heavier lambs at birth were heavier at 12 weeks of age e.g the progeny of the PD $x \mathrm{R}$ and $\mathrm{EF} \times \mathrm{R}$ ewes were heavier at birth than $\mathrm{F} \times \mathrm{R}$ (Table 2 ) and were still significantly heavier at 12 weeks (Table 5). Within a breed after adjusting for the sex of the lamb and birth rank, each extra kg birth weight resulted on average in an extra 1.2 to $1.7 \mathrm{~kg}$ at 12 weeks of age (Table 6).

\section{Summary}

Ewe effects played a significant role in lamb productivity and many of these effects were cumulative. Some of these were as expected i.e. the $\mathrm{F} x \mathrm{R}$ ewes had a higher lambing percentage and the progeny of $\mathrm{EF} x \mathrm{R}$ and $\mathrm{PD} x$ $\mathrm{R}$ ewes were heavier at birth and 12 weeks (Muir et al. 2000). However, the relationship between birth weight and mortality differed to that reported previously with the survival rates in heavier lambs being much better than the earlier reports. In high fecundity flocks increasing the average lamb birth weight should improve twin and triplet lamb survival. Whilst this may mean a small increase in dystocia as a result of heavier lambs, this should be offset by the increased survival of multiples. Ewe genotype also modified the effect of birth rank on birth weight with the average penalty for each additional lamb being smaller in progeny from $F \times R$ and $E F x R$ ewes than for the progeny of PD $x \mathrm{R}$ and $\mathrm{R}$ ewes. Ewes in the Elite Flock were generally maintained in good condition and this may explain why the effects of ewe body weight (within a genotype) had only a small effect on lamb birth weight. With good birth weights through nutrition and genetic selection, lambs reached slaughter weights sooner.

\section{ACKNOWLEDGEMENTS}

To the Poukawa staff; Graham Wallace, John Lane and Jacqui Bray, for data collection and stock management. Some of this work was carried out while AgResearch was running Poukawa Research Station. This work was sponsored by Meat New Zealand and WoolPro (now Meat and Wool New Zealand) and Richmond Ltd.

\section{REFERENCES}

Coop, I.E. 1962. Live weight-productivity relationships in sheep. New Zealand Journal of Agricultural Research 5: 249-264.

Coop, I.E. 1966. Effect of flushing on reproductive performance of ewes. Journal of Agricultural Science 67: 305-333.

Dalton, D.C.; Knight, T.W.; Johnson, D.L. 1980. Lamb survival in sheep breeds on New Zealand hill country. New Zealand Journal of Agricultural Research 23: 167-174.

Geenty, K.G. (Ed.) 1997. A guide to improved lambing percentage. Wools of New Zealand and the New Zealand Meat Producers Board. 75 pp.

Hight, G.K.; Jury, K.E. 1969. Lamb mortality in hill country flocks. Proceedings of the New Zealand Society of Animal Production 29: 219-232.

Hight, G.K.; Jury, K.E. 1970. Hill country sheep production. II Lamb mortality and birth weights in Romney and Border Leicester x Romney flocks. New Zealand Journal of Agricultural Research 13: 735-752.

Hinch, G.N.; Crosbie, S.F.; Kelly, R.W.; Owens, J.L.; Davis, G.H. 1985. Influence of birth weight and litter 
size on lamb survival in high fecundity BooroolaMerino crossbred flocks. New Zealand Journal of Agricultural Research 28: 31-38.

Morris, S.T.; Kenyon, P.R.; Burnham, D.L.; EverettHincks, J.M., 2003. The effect of sward height on twin and triplet lamb birth weights and survival rates to weaning. Proceedings of the New Zealand Society of Animal Production 63: 152-154.

Muir, P.D.; Smith, N.B.; Wallace, G.L.; Fugle, C.J.; Bown, M.D. 2000. Maximizing lamb growth rates. Proceedings of the New Zealand Grassland Association 62: 55-58. 
